\title{
Fungsi Taman Kota untuk Mitigasi Dampak Urban Heat Island di Kota Bandung
}

\author{
Ecological Function of Forest Park to Mitigate Urban Heat \\ Island in Bandung
}

\author{
DIAN ROSLEINE* ${ }^{*}$ ARKA IRFANI \\ Program Studi Biologi, Sekolah Ilmu dan Teknologi Hayati, Institut Teknologi Bandung, Jl. Ganeca No. 10 Bandung
}

Diterima 11 Februari 2020/Disetujui 4 Juni 2020

\begin{abstract}
Forest parks can take a role in mitigating negative impact of Urban Heat Island. Therefore, this study was conducted to clarify ecological function of three forest parks i.e Ganesha, Maluku, and Tegalega forest park in mitigating Urban Heat Island. Land classification and surface temperature were determined by analyzing Landsat 8 image with QGIS. Air temperature was measured by mobile station through north-south and east-west of Bandung City area. There are four types of land classification in Bandung as follows: settlements, water body, bare soil, and vegetation. In Bandung City, vegetation cover is around $20.72 \%$; surface temperatures in the afternoon varies from 23 to $39.6^{\circ} \mathrm{C}$, while during the night air temperatures varies from 20.5 to $24.9^{\circ} \mathrm{C}$. Northern part of Bandung tends to have cooler air temperature due to high coverage of vegetation. Tegalega forest park can reduce temperature up to $2.6^{\circ} \mathrm{C}$, while in Maluku forest park is $1.98^{\circ} \mathrm{C}$ and Ganesha forest park is $0.75^{\circ} \mathrm{C}$. Therefore, the existence of forest parks is important in urban area because they can take a part to reduce negative impact of Urban Heat Island.
\end{abstract}

Key words: Urban Heat Island, forest park, ecological function

\section{PENDAHULUAN}

Berdasarkan catatan dari PBB pada tahun 2014 dituliskan bahawa sebanyak $66 \%$ dari populasi dunia pada tahun 2050 diperkirakan akan tinggal di daerah perkotaan (UN 2014). Hal ini dapat menghasilkan berbagai dampak negatif yaitu peningkatan emisi $\mathrm{CO}_{2}$ dan peningkatan suhu lingkungan akibat dari peningkatan populasi manusia dan juga aktivitasnya seperti pengurangan tutupan vegetasi pada wilayah perkotaan (Feyisa et al. 2014; Al Mukmin et al. 2016; Nugroho et al. 2016; Zhang 2016). Fenomena perbedaan suhu antara kota dengan kawasan sekitarnya disebut dengan Urban Heat Island (UHI) (Manik dan Syaukat 2015).

Oke (1987) menyatakan bahwa UHI dapat menyebabkan peningkatan suhu di daerah perkotaan sebanyak $1-3^{\circ} \mathrm{C}$ dari lingkungan sekitarnya. Pada kasus ekstrem, perbedaan suhu dapat mencapai $12^{\circ} \mathrm{C}$ atau lebih. Di Tokyo, Jepang tercatat perbedaan suhu sebanyak $12^{\circ} \mathrm{C}$ di dalam kota dengan daerah di sekitarnya. Di Atlanta, Amerika tercatat perbedaan suhu udara antara kawasan kota dan di daerah sekitarnya sebesar $1.2^{\circ} \mathrm{C}$, sedangkan di Seoul, Korea Selatan sebanyak $8^{\circ} \mathrm{C}$ (Clay et al. 2016).

*Penulis korespondensi:

E-mail: drosleine@gmail.com
Urbanisasi di Kota Bandung saat ini terjadi dengan sangat cepat. Akibatnya, banyak hutan dan kawasan hijau berupa areal persawahan, taman kota, dan jalur hijau yang dikonversi menjadi perumahan, bangunan, dan kawasan industri (Tursilowati 2002). Peningkatan suhu di daerah perkotaan dapat memberikan dampak negatif, seperti peningkatan polusi udara dan peningkatan konsumsi energi terutama karena penggunaan pendingin ruangan. Kondisi ini pada akhirnya dapat memengaruhi perubahan iklim (Arifwidodo dan Chandrasiri 2015; Al Mukmin et al. 2016).

Terdapat beberapa cara untuk memitigasi dampak UHI, diantaranya adalah penggunaan material dengan albedo (kemampuan memantulkan cahaya) tinggi, penanaman tumbuhan, atau kombinasi antara keduanya (Taha 1997; Sodoudi et al. 2014; Wang et al. 2018). Penanaman pohon merupakan cara yang paling efektif untuk memitigasi UHI karena dapat membantu mendinginkan lingkungan dengan memberikan naungan dan pengeluaran uap air melalui proses evapotranspirasi (Bristow et al. 2010; Ancu et al. 2014; Sodoudi et al. 2014). Ningrum dan Narulita (2015) mencatat bahwa kisaran suhu permukaan Kota Bandung adalah 7.18-36.0 $0^{\circ} \mathrm{C}$ pada tahun 2005 menjadi $10.24-39.0^{\circ} \mathrm{C}$ pada tahun 2015 karena terjadi perubahan tutupan lahan. Keberadaan taman kota yang masih banyak dijumpai di Kota 
Bandung diperkirakan dapat memberikan fungsi ekologis terutama dalam mitigasi suhu (Bristow et al. 2010; Feyisa et al. 2014). Oleh karena itu, pengamatan fenomena UHI di Kota Bandung menjadi menarik karena dapat melihat fungsi taman kota dalam memitigasi suhu. Selain itu, masih sedikit informasi mengenai gambaran fenomena UHI di Kota Bandung sehingga data ini dapat dijadikan masukan dalam pengelolaan taman kota.

\section{BAHAN DAN METODE}

Metodologi Penelitian. Penelitian ini dibagi menjadi dua bagian yaitu pengamatan suhu untuk menggambarkan fenomena UHI di Kota Bandung dan pengamatan secara langsung di beberapa taman kota untuk melihat fungsinya dalam memitigasi suhu. Fenomena UHI dapat dibagi menjadi dua jenis yaitu UHI Permukaan yang dapat diketahui dengan menganalisis suhu melalui citra satelit dan UHI udara dengan mengukur suhu secara langsung di lapangan. Pengambilan data dilakukan pada bulan Juni-Juli 2018. Musim kemarau dipilih sebagai waktu yang cocok untuk mencatat suhu karena suhu udara cenderung stabil dan tidak terganggu oleh hujan (Suaydhi 2016).

Pengolahan Citra. Data suhu Kota Bandung diperoleh dari citra Landsat 8 tanggal 6 Juni 2018 pukul 11:53 dari website USGS pada path 122/row 65 yang kemudian diolah dengan menggunakan software qGIS 3.2. Pengolahan data pada qGIS dibantu dengan menggunakan plugins SemiAutomatic Classification Plugins (SCP). Tutupan lahan diklasifikasikan menjadi badan air, bangunan, vegetasi, dan lahan terbuka. Pada tahapan ini digunakan Ladsat 8 Band 2, 3, 4, 5, 6, dan 7.

Koreksi atmosferik dilakukan untuk memastikan bahwa citra yang dihasilkan sesuai dengan keadaan lapangan. Kemudian peta dibatasi dengan menggunaan peta kawasan Kota Bandung. Normalized Difference Vegetation Index (NDVI) dihitung untuk menghubungkan antara tingkat kesehatan tumbuhan dan kemampuannya dalam menurunkan suhu lingkungan (Fawzi 2014).

Pengukuran UHI melalui Suhu Permukaan Kota Bandung. Citra Landsat 8 Band 10 yang merupakan Thermal Infrared digunakan untuk mengukur suhu permukaan, kemudian dianalisis dengan menggunakan bantuan plugins SCP. Hasil klasifikasi lahan yang telah dilakukan sebelumnya diklasifikasi ulang dengan menggunakan nilai emisivitas dari tiap jenis tutupan lahan. Nilai emisivitas (Tabel 1) dari tiap tutupan lahan dilakukan dengan mengacu pada penelitian oleh Mallick et al. 2012, pada tahun 2012.

Hasil klasifikasi ulang kemudian dikonversi menjadi suhu permukaan dengan menggunakan persamaan yang digunakan dalam penelitian Weng et al. (2004).
Tabel 1. Nilai emisivitas

\begin{tabular}{ll}
\hline Tipe tutupan lahan & Nilai emisifitas \\
\hline Lahan terbuka & 0.928 \\
Vegetasi & 0.982 \\
Bangunan & 0.937 \\
Air & 0.98 \\
\hline
\end{tabular}

$\mathrm{T}=\mathrm{TB} /[1+(\lambda * \mathrm{~TB} / \mathrm{c} 2) * \ln (\mathrm{e})$

Dengan:

$\mathrm{T} \quad$ :Suhu permukaan $\left({ }^{\circ} \mathrm{C}\right)$

$\mathrm{Tb} \quad$ :Suhu satelit (Band 10)

$\lambda \quad$ :Panjang gelombang radiasi

$\mathrm{c} 2 \quad: \mathrm{h} * \mathrm{c} / \mathrm{s}=1.4388 * 10-2$

h :Konstanta plank $\left(6.626 * 10^{-34} \mathrm{~J} \mathrm{~s}\right)$

c $\quad:$ Kecepatan cahaya $\left(2.998 * 10^{8} \mathrm{~m} / \mathrm{s}\right)$

s :Konstanta boltzman/nilai emisivitas $\left(1.38 * 10^{-23} \mathrm{~J} / \mathrm{K}\right) \mathrm{e}$

Pengukuran NDVI Kota Bandung. NDVI merupakan indeks yang dapat mengukur tingkat kehijauan vegetasi dengan membandingkan spectral NIR dengan gelombang merah (Ardiansyah 2015). Indeks ini dapat berfungsi untuk mengetahui tingkat kerapatan vegetasi yang menyusun suatu area yang dapat dikaitkan dengan suhu permukaan. Perhitungan NDVI menggunakan dua band dari citra Landsat 8 yaitu band 4 (merah) dan band 5 (NIR), dengan menggunakan rumus pengolahan sebagai berikut:

$$
\mathrm{NDVI}=\frac{\text { Band } 5-\text { Band } 4}{\text { Band } 5+\text { Band } 4}
$$

Dengan:

Band 4 : Band saluran merah pada citra Landsat 8 Band 5 : Band saluran NIR pada citra Landsat 8

Nilai NDVI yang mendekati 1 menunjukkan tutupan vegetasi semakin rapat, sedangkan jika NDVI mendekati 0 menyatakan tutupan vegetasi jarang atau tidak terdapat vegetasi (Tursilowati 2002).

Pengukuran UHI Suhu Udara Kota Bandung. Suhu udara diukur dengan mengikuti metode yang digunakan oleh Wong dan Chen di Singapura dan Clay et al. (2016) di Adelaide menggunakan data logger HOBO pendant yang dipasangkan di atas kendaraan (3 m diatas permukaan tanah; kecepatan sekitar $30 \mathrm{~km} / \mathrm{jam})$. Interval data logger adalah 1 menit di jalur utara-selatan dan barat-timur Kota Bandung yang mewakili perbedaan tutupan vegetasi. Jalur pengambilan data suhu udara dapat dilihat pada Gambar 1. Pengambilan data dilakukan dengan empat kali pengulangan pada malam hari pukul 00.00-02.00 karena fenomena UHI dapat teramati jelas pada malam hari (Clay et al. 2016).

Fungsi Taman Kota untuk Mitigasi UHI. Tiga taman kota yaitu Taman Ganesha, Taman Maluku, dan Taman Tegalega (Gambar 2) dipilih sebagai 
lokasi penelitian karena ketiga lokasi memiliki karakteristik yang berbeda dari segi komposisi vegetasi dan penataan vegetasi di dalam taman. Pengambilan data suhu taman mengikuti metode yang dilakukan oleh Wong dan Chen (2009) yang dilakukan di Singapura. Pencatatan suhu udara dilakukan di beberapa titik bagian luar dan dalam taman dengan tiga kali pengulangan pada waktu 12.00-13.00, 15.00-16.00, dan 18.00-19.00 WIB. Waktu tersebut dipilih berdasarkan intensitas

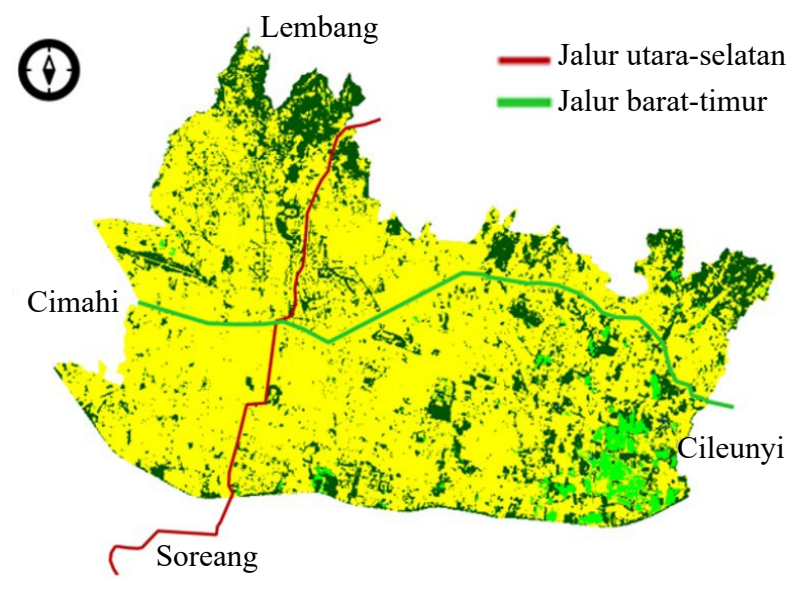

Gambar 1. Jalur pengambilan suhu udara cahaya matahari yang cenderung berbeda pada jamjam tersebut (Wong dan Chen 2009).

Perhitungan Tutupan Kanopi Taman. Pada penelitian ini digunakan DJI Phantom 4 Advance untuk pengambilan gambar yang memiliki sensor CMOS 20 megapixel. Pengambilan foto dilakukan pada ketinggian $80 \mathrm{~m}$ di atas permukaan tanah dan diatur dengan menggunakan aplikasi dronedeploy. Gambar diatur agar memiliki keselingkupan (overlap) sebesar $80 \%$ yang kemudian diolah dengan menggunakan aplikasi $3 d$ Survey sehingga menghasilkan model tiga dimensi dari taman. Model 3 dimensi dari tiap taman kemudian diolah menjadi peta ketinggian dengan menggunakan applikasi sehingga didapatkan peta kontur. Daerah yang tidak tertutup oleh kanopi akan berwarna biru yang menandakan titik terendah pada model. Daerah tersebut kemudian dihitung untuk menentukan perbandingan areal berkanopi dengan keseluruhan areal taman.

Perhitungan Jumlah Pohon Taman. Pencatatan jumlah vegetasi pohon yang memiliki diameter $>10$ cm dilakukan di ketiga taman dengan menggunakan menggunakan metode sensus. Metode perhitungan ini dilakukan dengan mengikuti pengambilan data

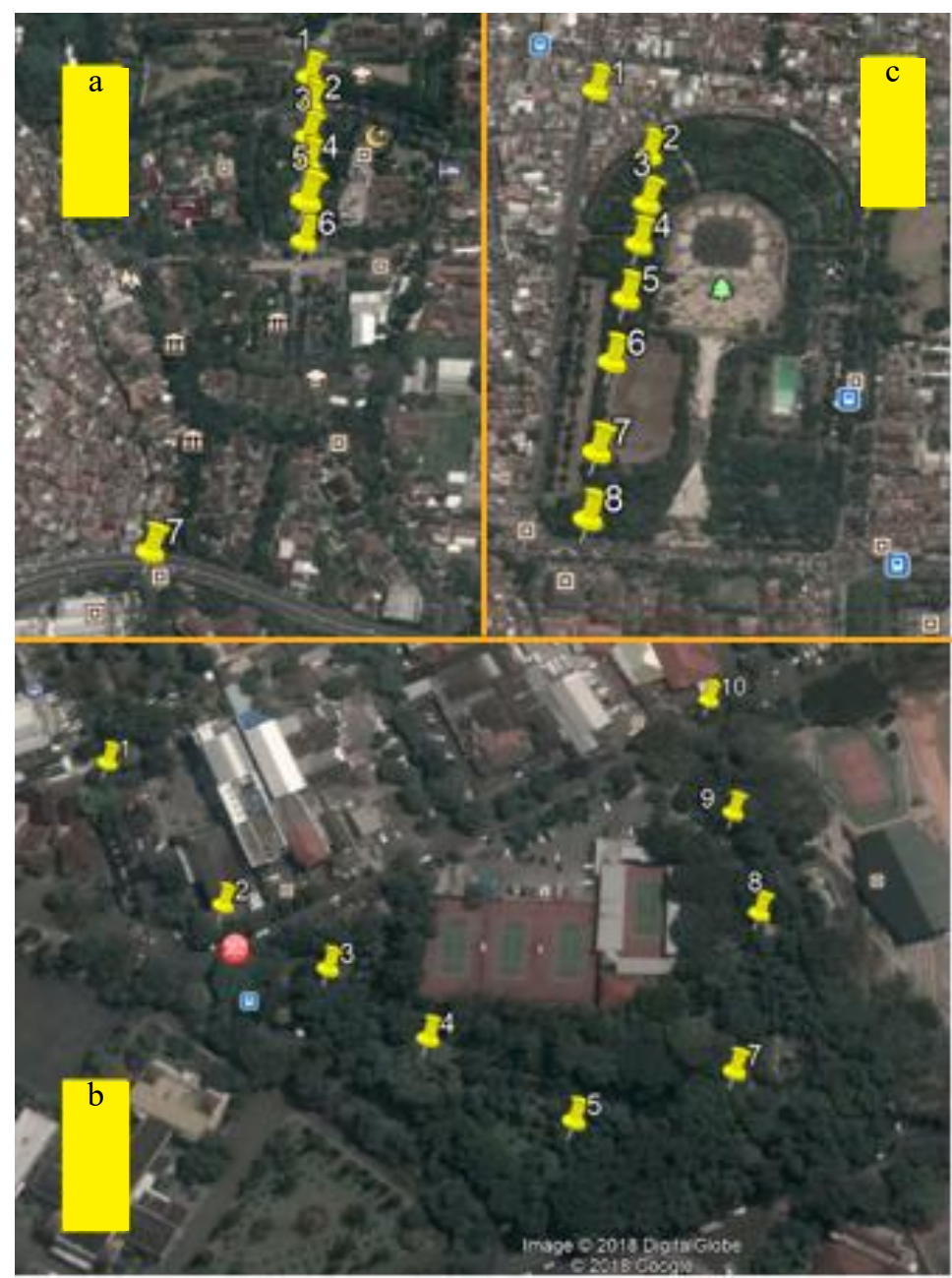

Gambar 2. (a) Taman Ganesha, (b) Taman Maluku, dan (c) Taman Tegalega 
oleh Indrajaya dan Mulyana (2017) di Kebung Binatang Tamansari Kota Bandung.

\section{HASIL}

Tutupan Lahan Kota Bandung Tahun 2018. Tipe tutupan lahan di Kota Bandung bervariasi dari mulai kawasan terbuka, pemukiman, badan air, dan tutupan vegetasi. Hal ini dapat dilihat dari hasil nilai NDVI yang beragam (-0.399 0.856). Nilai NDVI tinggi menunjukkan penutupan vegetasi yang rapat, sedangkan nilai NDVI rendah menunjukkan kawasan terbuka.

Berdasarkan pengolahan citra Landsat 8 diketahui bahwa tutupan vegetasi pada Kota Bandung adalah sebesar $20.72 \%$ dengan persentase tertinggi di kawasan utara dan nilai NDVI berkisar 0.742 hingga 0.856. Kota Bandung dengan laju pembangunan yang tinggi mengakibatkan terjadi penurunan ruang terbuka hijau (RTH). Kawasan terbuka dapat dilihat di bagian tenggara Kota Bandung yang merupakan persawahan kering dan pusat kota yang didominasi oleh bangunan. Nilai NDVI di kawasan ini rendah, berkisar -0.0567 hingga 0.0574 . Kondisi seperti ini dapat menyebabkan peningkatan suhu udara di Kota Bandung. Perbedaan nilai tersebut dihasilkan oleh perbedaan kemampuan tumbuhan untuk merefleksikan cahaya. Klasifikasi tutupan lahan dan persebaran nilai NDVI di Kota Bandung dapat dilihat pada Gambar 3.

UHI Pada Suhu Permukaan Kota Bandung. Analisis data citra Landsat 8 menunjukkan bahwa suhu permukaan tertinggi berada di daerah perumahan, bangunan, dan industri (Gambar 4), sedangkan suhu lebih rendah ditemukan di daerah yang tertutup vegetasi seperti di kawasan Bandung Utara $\left(23^{\circ} \mathrm{C}\right)$. Perbedaan suhu maksimum yang tercatat sebesar $16.6^{\circ} \mathrm{C}$ antara daerah yang masih ditutupioleh vegetasi dengan daerah yang didominasi oleh bangunan. Nilai NDVI berbanding terbalik dengan suhu, dimana daerah dengan NDVI tinggi memiliki suhu permukaan yang lebih rendah karena pohon dapat memberikan naungan, sedangkan nilai NDVI rendah menunjukkan kawasan yang terbuka karena naungan tersebut dapat mengurangi panas yang terserap oleh lingkungan. Selain itu, uap air yang dikeluarkan melalui proses transpirasi dapat membantu mendinginkan suhu lingkungan dengan melepaskan kembali energi panas melalui penguapan air.

\section{UHI Pada Suhu Udara Kota Bandung.}

Suhu Udara Kota Bandung pada Jalur BaratTimur. Suhu udara dicatat pada malam hari karena fenomena UHI akan teramati pada malam hari. Data suhu sepanjang jalur pengamatan dapat dilihat pada Gambar 5. Kawasan dengan suhu permukaan tinggi pada siang hari cenderung mempertahankan panas hingga malam. Bangunan cenderung mempertahankan panas lebih lama dibandingkan dengan vegetasi, oleh karena itu daerah yang dipenuhi oleh bangunan akan memiliki suhu udara malam hari yang lebih tinggi. Hasil pengambilan suhu udara pada jalur Barat-Timur dapat diamati pada Gambar 6.

Secara umum perbedaan suhu udara tertinggi dengan suhu udara terendah di jalur barattimur adalah $0.5^{\circ} \mathrm{C}$. Namun, ditemukan gradien perubahan suhu di sepanjang jalur pengamatan
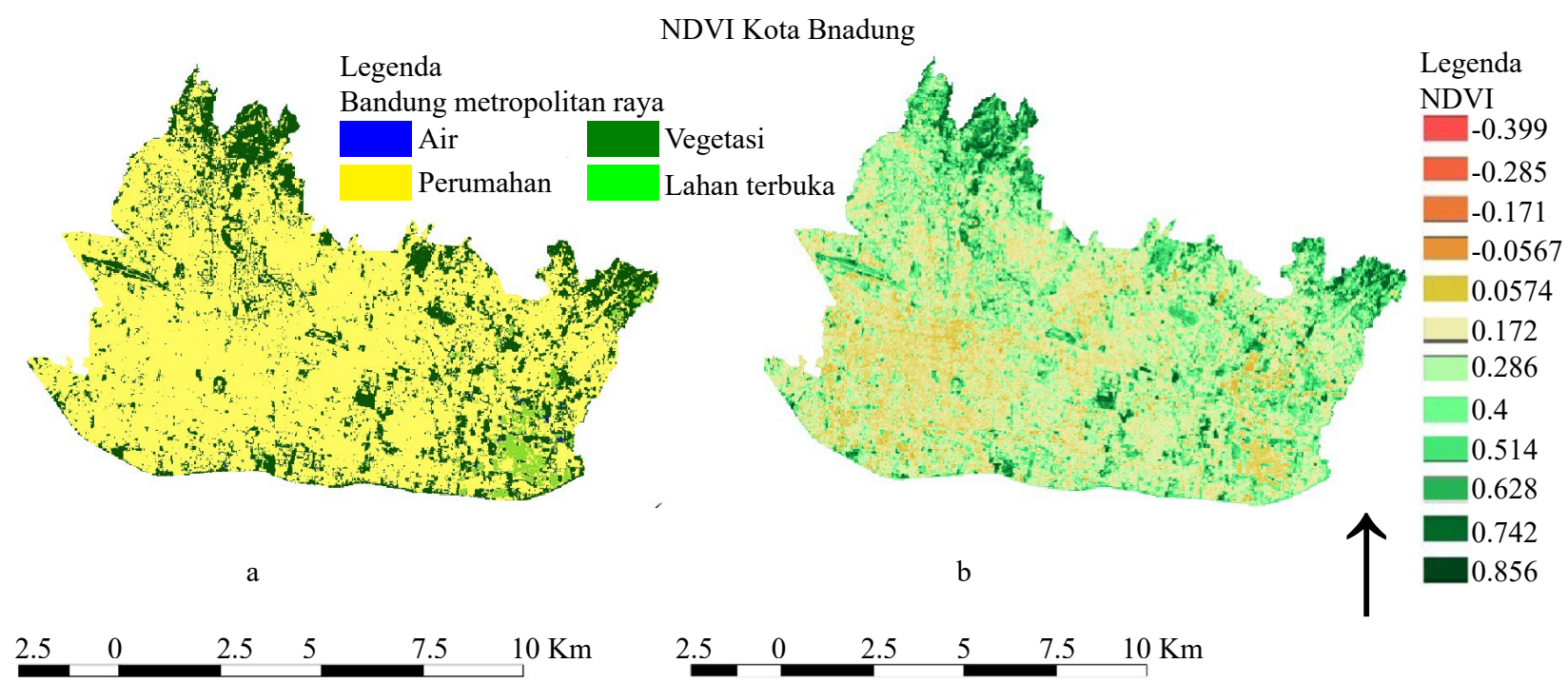

Gambar 3. (a) Klasifikasi tutupan kota Bandung, (b) persebaran nilai 


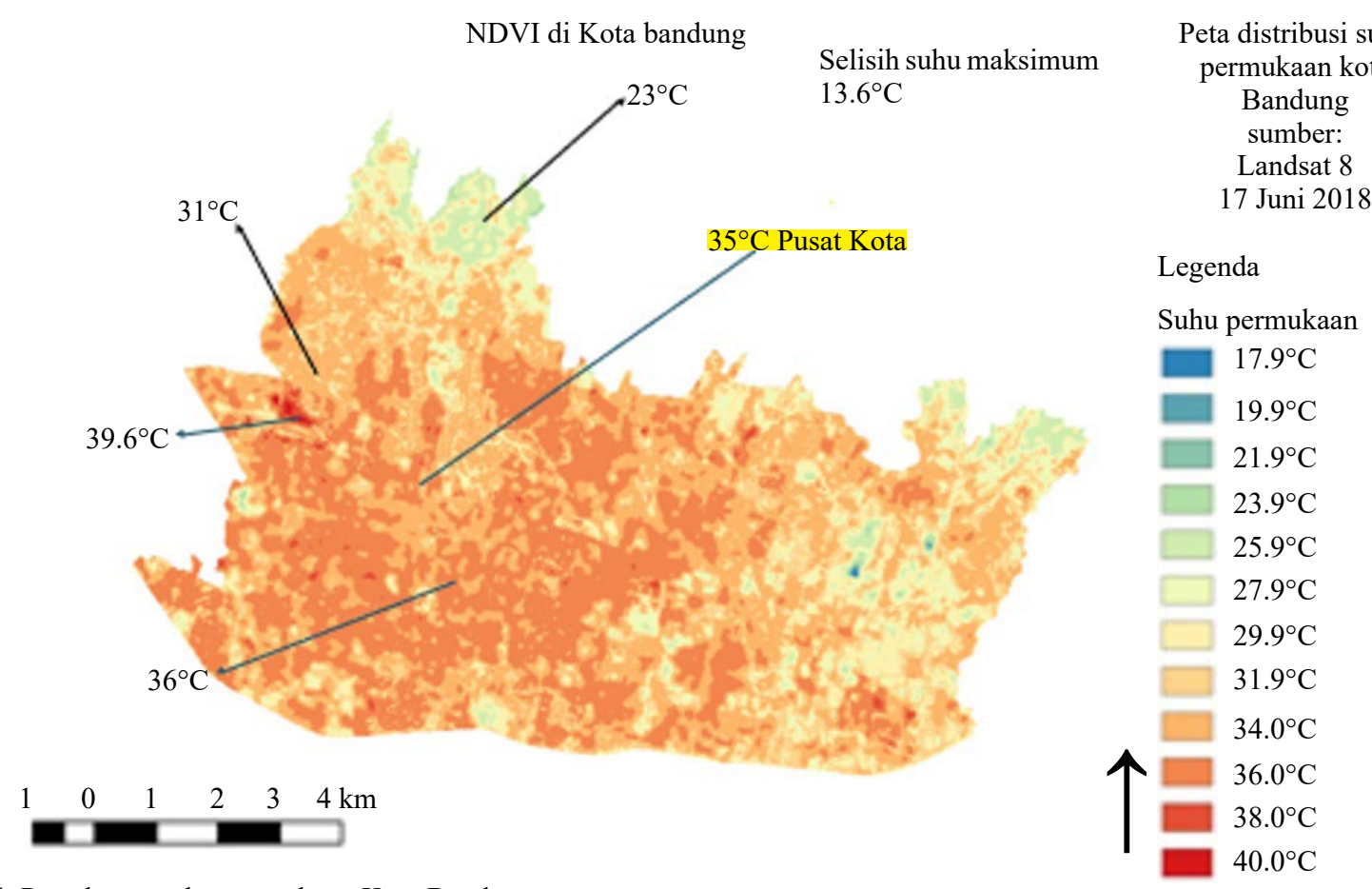

Gambar 4. Persebaran suhu permukaan Kota Bandung

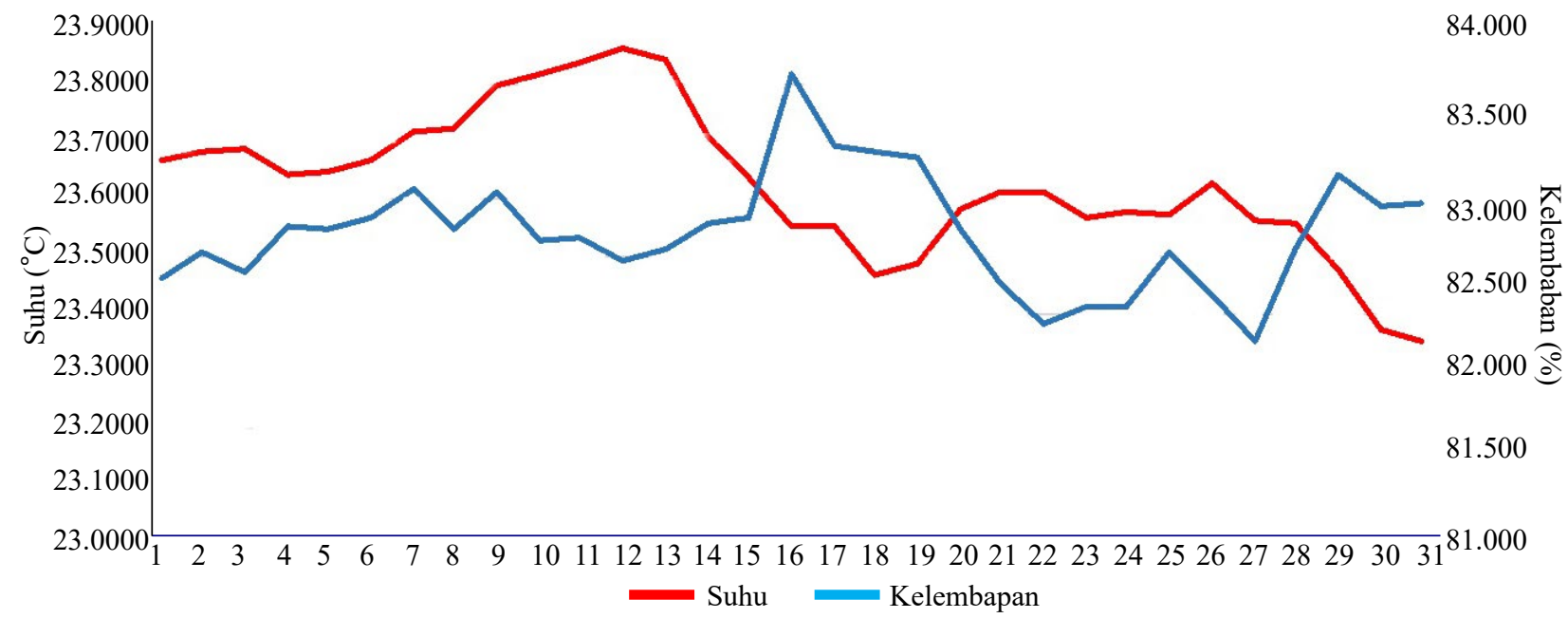

Gambar 5. Tren suhu Kota Bandung jalur Barat-Selatan. Titik-titik pengambilan data dinyatakan dengan angka 1 (awal pengambilan data) hingga 31 (titik akhir pengambilan data)

Barat-Timur. Kawasan yang tertutup vegetasi pada jalur ini memiliki nilai NDVI tinggi (0.524$0.825)$. Kawasan yang tertutup vegetasi cenderung memiliki kelembaban yang tinggi. Suhu udara yang tinggi dijumpai di daerah pusat kota $\left(23.8^{\circ} \mathrm{C}\right.$ pada titik pengamatan 12) karena banyak dijumpai bangunan yang rapat (NDVI 0.057-0.2), kemudian menurun karena beberapa titik merupakan kawasan bervegatasi termasuk taman kota.

Suhu Udara Kota Bandung pada Jalur UtaraSelatan. Pada jalur utara-selatan teramati perbedaan suhu udara hingga $3.2^{\circ} \mathrm{C}$ (Gambar 6). Suhu terendah tercatat di kawasan utara Kota Bandung $\left(20.3^{\circ} \mathrm{C}\right)$ yang masih memiliki tutupan hijau yang rapat dengan nilai NDVI yang tinggi (0.628-0.825).

Pengamatan dari jalur utara-selatan Kota Bandung diketahui bahwa suhu tertinggi teramati pada daerah pusat kota sebesar $23.5^{\circ} \mathrm{C}$ (Gambar 6). Penurunan suhu sebesar $0.2^{\circ} \mathrm{C}$ ditemukan di kawasan Taman Kota Tegalega yang dinyatakan oleh titik pengambilan sampel nomor 31-33. Suhu pada siang hari dan malam hari di daerah yang bervegetasi cenderung relatif tidak berbeda jauh dibandingkan dengan kawasan yang tidak tertutup oleh vegetasi. Daerah yang terbuka cenderung memiliki perbedaan suhu siang dan malam yang tinggi.

\section{PEMBAHASAN}

Fenomena UHI di Kota Bandung, baik itu untuk suhu permukaan maupun suhu udara dipengaruhi oleh kerapatan vegetasi (Gambar 4). Tumbuhan dengan bentuk hidup pohon dapat menurunkan 


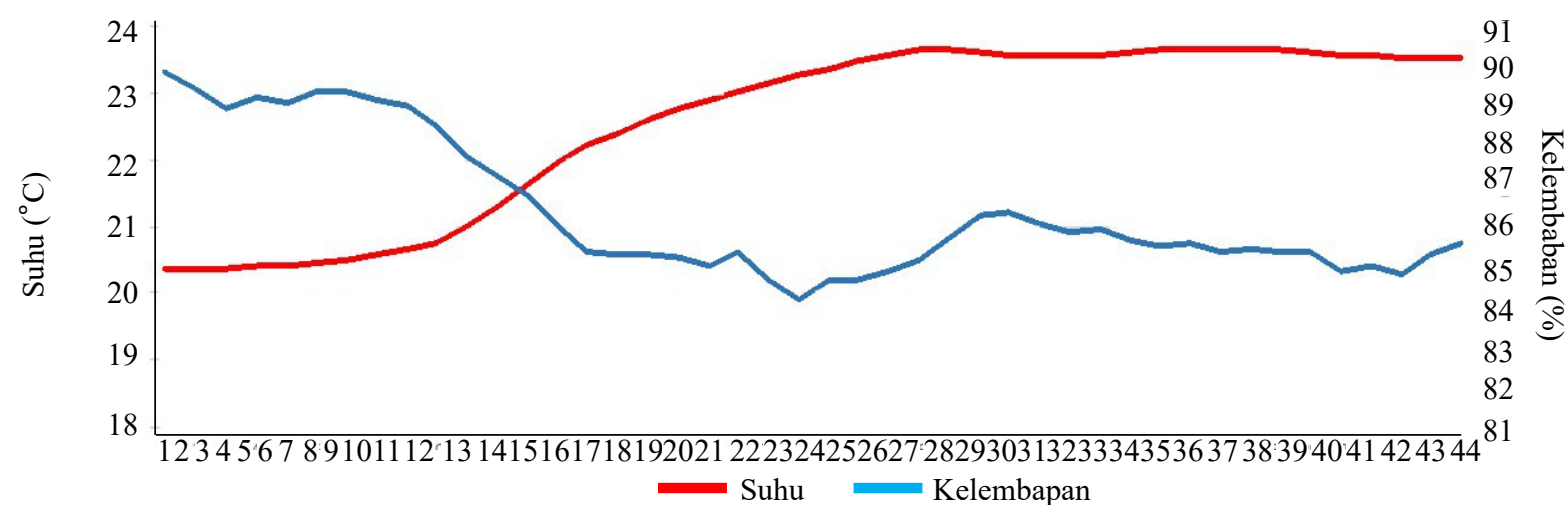

Gambar 6. Tren suhu Kota Bandung jalur Utara-Selatan. Titik-titik pengambilan data dinyatakan dengan angka 1 (awal pengambilan data, utara) hingga 31 (titik akhir pengambilan data)

suhu karena memiliki nilai albedo yang lebih tinggi bila dibandingkan dengan material bangunan. Albedo merupakan nilai perbandingan antara cahaya matahari yang dipantulkan, oleh karena itu, semakin tinggi albedo maka semakin banyak cahaya matahari yang dipantulkan dan tidak diserap (Feyisa et al. 2014; Sodoudi et al. 2014; Dede et al. 2019).

Berdasarkan UU Republik Indonesia tentang Penataan Ruang No 26 tahun 2007 diketahui bahwa sebuah kota minimal memiliki tutupan hijau $30 \%$ dari total luas kota. Dengan demikian, Kota Bandung perlu menambahkan jumlah tutupan hijau dalam kota karena pada tahun 2015, luasan ruang terbuka hijau (RTH) kota Bndung hanya sebesar $12.15 \%$ (Naf dan Hernawati 2018).

\section{Peranan Taman Kota untuk Mitigasi UHI.}

Taman Tegalega. Taman Tegalega merupakan taman yang memiliki ukuran paling luas pada penelitian ini yaitu 17.3 Ha (Gambar 2). Pohon yang ditanam di kawasan ini relatif rapat dengan jarak tanam antara 2.5-3.0 m. Kerapatan pohon berdasarkan sensus adalah 95 Pohon/Ha dengan kerimbunan 60.5\%. Di Kawasan Taman Tegalega, penurunan suhu terjadi di dalam taman kota dan meningkat di bagian luar taman. Perbedaan suhu di bagian luar dan dalam taman sebesar $3.5^{\circ} \mathrm{C}$ dengan rata-rata suhu di dalam taman mencapai $27.3^{\circ} \mathrm{C}$ dan di luar taman mencapai $29.9^{\circ} \mathrm{C}$. Dengan demikian terlihat bahwa taman kota ini berfungsi secara ekologi dalam menurunkan suhu udara. Menurunnya suhu di dalam taman kota dapat disebabkan karena rapatnya pepohonan sehingga suhu cenderung konstan di bawah kanopi pohon. Selain itu vegetasi seperti yang dilaporkan oleh Wang et al. (2018) dan Aram et al. (2019) dapat memberikan efek pendinginan yang baik pada suatu area.

Taman Ganesha. Taman Ganesha memiliki luas sebesar 1.27 Ha. kerapatan pohon di kawasan ini adalah 110 Pohon/Ha dengan kerimbunan sebesar $64.7 \%$. Taman Ganesha memiliki karakteristik yang berbeda dengan Taman Tegalega dengan pohon yang rapat. Taman Ganesha memiliki daerah terbuka di bagian tengah taman yang dilengkapi dengan kolam kecil (Gambar 2). Tercatat selisih suhu maksimum antara bagian luar taman dan bagian dalam taman sebesar $1.1^{\circ} \mathrm{C}$ dengan rata-rata suhu di dalam mencapai $27.46^{\circ} \mathrm{C}$ dan di luar mencapai $28.21^{\circ} \mathrm{C}$. Jika dibandingkan dengan Tegalega, selisih suhu di Taman Ganesha cenderung lebih kecil karena banyaknya daerah terbuka pada taman. Keberadaan kolam yang tidak ternaungi juga menyebabkan peningkatan suhu pada bagian dalam taman karena air memiliki kemampuan mempertahankan panas (Sodoudi et al. 2014; Clay et al. 2016).

Taman Maluku. Taman Maluku dengan luas sebesar $1.9 \mathrm{Ha}$ memiliki kerapatan pohon 102 pohon/Ha. Di antara ketiga taman yang diamati, Taman Maluku memiliki kerimbunan kanopi yang paling tinggi yaitu $85.73 \%$. Pohon-pohon dengan ukuran besar (diameter $>40 \mathrm{~cm}$ ) banyak ditemukan di kawasan ini. Selisih suhu maksimum pada siang hari antara bagian luar dan bagian dalam di Taman Maluku sebesar $4.2^{\circ} \mathrm{C}$ dengan selisih suhu rata-rata antara bagian dalam dan bagian luar taman sebesar $1.98^{\circ} \mathrm{C}$.

Penurunan suhu yang besar di dalam taman dapat disebabkan oleh keberadaan kolam yang tertutup oleh pohon. Air pada kolam tidak terpapar matahari secara langsung, oleh karenanya suhu air relatif lebih dingin jika dibandingkan dengan air kolam di Taman Ganesha. Selain itu, pohonpohon yang besar membantu menurunkan suhu udara (Sodoudi et al. 2014). Tingginya suhu di luar taman dikarenakan aktivitas manusia yang yang tinggi seperti penggunaan kendaraan bermotor dan banyaknya bangunan di di sekitar taman.

\section{KESIMPULAN}

Fenomena UHI (Urban Heat Island) di Kota Bandung termati dengan ditemukannya perbedaan suhu permukaan $\left(16.6^{\circ} \mathrm{C}\right)$ dan suhu udara $\left(3.3^{\circ} \mathrm{C}\right)$ antara pusat kota dengan daerah pinggiran kota bagian utara yang masih memiliki tutupan vegetasi tinggi. Fenomena UHI di dalam kota dapat dikurangi dengan keberadaan taman kota, meskipun peranan taman kota akan bergantung pada tipe tutupan vegetasi, kerapatan, dan kerimbunan kanopi. 
Taman Tegalega dengan kerapatan pohon yang tinggi (95 pohon per ha) dan kerimbunan $60.5 \%$ dapat menurunkan suhu udara sebanyak $3.5^{\circ} \mathrm{C}$, kemudian Taman Maluku yang memiliki kerapatan pohon 102 per ha dan kerimbunan $85.73 \%$ dapat menurunkan suhu udara sebesar $4.2^{\circ} \mathrm{C}$, dan Taman Ganesha dengan kerapatan pohon 110 per ha dengan kerimbunan $64.7 \%$ hanya mampu menurunkan suhu sebesar $1.1^{\circ} \mathrm{C}$.

Berdasarkan pengamatan, jarak tanam pohon yang konstan dapat mempertahankan stabilitas suhu di dalam taman. Selain itu, kolam yang tertutup vegetasi mampu menurunkan suhu lingkungan lebih baik dibandingkan dengan kolam yang terbuka.

\section{UCAPAN TERIMA KASIH}

Kami ucapkan terima kasih kepada pengelola Taman Tegalega, Taman Maluku, dan Taman Ganesa yang telah memberikan izin untuk melakukan penelitian di tiga kawasan ini.

\section{DAFTAR PUSTAKA}

Al Muknim SA, Wijaya AP, Sukmono A. 2016. Analisis pengaruh perubahan tutupan lahan terhadap distribusi suhu permukaan dan keterkaitannya dengan fenomena Urban Heat Island. Jurnal Geodesi Undip 5:224-233.

Ancu S, Chitu E, Marin FC, Ancu I, Plopa C. 2014. Correlation of Stomatal Conductance with Photosynthetic Capacity of Six Walnut Cultivars from the National Assortment. South Western Journal of Horticulture 5:1-10.

Aram FA, Garcia EH, Solgi E, Mansournia S. 2019. Urban green space cooling effect in cities. Heliyon 5:e01339.

Araus J, Casadesus J, Bort J. 2001. Recent tools for the screening of physiological traits determining yield. Application of physiology in wheat breeding 2001:59-77.

Ardiansyah. 2015. Pengolahan CItra Pengindraan Jauh menggunakan ENVI 5.1 dan ENVI LiDAR. Jakarta: PT. LABSIG INDERAJA ISLIM.

Arifwidodo S, Chandrasiri. 2015. Urban eat Island and Houshold Energy Consumption in Bangkok, Thailand. Energy Proceeding 79:189-194.

Ballinas M, Barradas VL. 2015. The Urban Tree as a Tool to Mitigate Urban Heat Island in Mexico City:a Simple phenomenological model. Journal of Environmental Quality 45:10-11.

Bristow RS, Blackie R, Brown N. 2010. Park and the urban heat island: alongitudinal study in Westfield, Massachusetts. Proceeding of the 2010 Notheastern Recreation Research Symposium 94:224-230.

Clay R, Guan H, Wild N, Bennet J, Vinodkumar, Ewenz C. 2016. Urban heat island traverses in the City of Adelaide, South Australia. Urban Climate 17:89-101.

Dede M, Pramulatsih GP, Widiawaty MA, Ramadhan YR, Ati A. 2019. Dinamika suhu permukaan dan kerapatan vegetasi di Kota Cirebon. Jurnal Meteorologi Klimatologi dan Geofisika 6:23-31.
Fawzi NI. 2014. Pemetaan emisivitas permukaan menggunakan indeks vegetasi. Majalah Ilmiah Globe 16 :133-139.

Feyisa GL, Dons K, Meilby H. 2014. Efficiency of park in mitigating urban heat island effect:an example from Addis Ababa. Lanscape and Urban Planning 123: 87-95.

Indrajaya Y, Mulyana S. 2017. Simpanan Karbon Dalam Biomassa Pohon di Hutan Kota Kebun Binatang Bandung. In: Prosiding Seminar Nasional Geografi UMS 2017. Solo: Pengelolaan Sumberdaya Wilayah Berkelanjutan.

Mallick J, Singh C, Shashtri SR. 2012. Land Surface emissivity retrieval based on moisture index from Landsat TM satellite data over heterogeneous surfaces of Delhi city. International Journal of Applied Earth Observation and Geoinformation 19:348-358.

Manik TK, Syaukat S. 2015. The impact of urban heat islands: assesing vulnerability in Indonesia. Asian Cities Climate Resilience: Working Paper Series 13:8-9.

Naf MZ, Hernawati R. 2018. Analisis fenomena UHI (Urban Heat Island) berdasarkan hubungan antara kerapatan vegetasi dengan suhu permukaan. ITB Indonesian Journal of Geospatial 5:25-36.

Ningrum W, Narulita I. 2015. Deteksi perubahan suhu permukaan menggunakan data satelit landsat multi-waktu (studi kasus Cekungan Bandung). Jurnal Teknologi Lingkungan 19: 145-154.

Nugroho SA, Wijaya AP, Sukmono A. 2016. Analisis pengaruh perubahan vegetasi terhadap suhu permukaan di wilayah Kabupaten Semarang menggunakan metode penginderaan jauh. Jurnal Geodesi Undip 5:253-263.

Oke T. 1987. Boundary Layer Climates. New York: Routledge.

Sodoudi S, Shahmohamadi P, Vollack K, Cubasch U, Che-Ani AI. 2014. Mitigating urban heat island effect in Megacity Tehran. Advances in Meteorology 2014:1-19.

Suaydhi. 2016. Karakteristik awal dan panjang musim di Indonesia. In: Prosiding Pertemuan Ilmiah XXX HFI Jateng sN DIY. Salatiga. p. 109-114.

Taha H. 1997. Urban climates and heat islands:albedo, evapotranspiration, and anthtropogenic heat. Energy and Building 25:99-103.

Tursilowati L. 2002. Urban Heat Island dan Kontribusinya pada Perubahan Iklim dan Hubungannya dengan Perubahan Lahan. In:Prosiding Seminar Nasional Pemanasan Global dan Perubahan Global - Fakta, Mitigasi, dan Adaptasi. Pusat Pemanfaatan Sains dan Atmosfer Iklim LAPAN p. 89-96.

UN. 2014. World Urbanization Prospects: Highlights 2014 Revision. New York: UN.

Wang X, Cheng H, Xi J, Yang G, Zhao Y. 2018. Relationship between park composition, vegetation characteristics and cool island effect. Sustainability 10:1-14.

Weng Q, Lu D, Schubring J. 2004. Estimation of land surface temperature-vegetation abundance relationship for urban heat island studies. Remote Sensing of Environment 89:467-483.

Wong NH, Chen Y. 2009. Tropical Urban Heat Islands: Climate, buildings, and greenery. New York: Taylor and Francis.

Zhang XQ. 2016. The trends, promises and challenges of urbanization in the world. Habitat International 54:241252. 